Journal of Clinical Investigation

Vol. 41, No. 10, 1962

\title{
PRESSURE-VOLUME CHARACTERISTICS OF THE HUMAN COLON
}

\author{
By MARTIN LIPKIN, THOMAS ALMY, AND BERTRAND M. BELL
}

(From the Department of Medicine, Cornell University Medical College, and the Second [Cornell] Medical Division, Bellevue Hospital, New York, N. Y.)

(Submitted for publication June 16, 1961 ; accepted June 7, 1962)

The activity of the muscular lining of the human colon has customarily been measured in terms of phasic variations of the intraluminal pressure, and less commonly in terms of changes in volume of inlying balloons. By such means, alterations of wave patterns have been recorded in abnormal physiological states, after the administration of pharmacologic agents, and in diseases of the colon. Estimates made from such recordings of the tonus or level of sustained contractions of the muscular wall have been widely regarded as unsatisfactory. With such limitations of our knowledge of colonic motility, additional parameters would appear desirable.

In the present study, changes produced by distension in the pressure and volume of a segment of the human sigmoid colon were recorded simultaneously. Mathematical analysis of the data has provided measurements of the rate of distension and accommodation of the colonic wall to the stretching force. The relationships of these parameters to muscular activity are indicated by alterations resulting from the action of pharmacologic agents.

\section{METHODS}

Apparatus. The apparatus used in these experiments is shown diagrammatically in Figure 1 . Chamber $A$ is a cylindrical water reservoir $45 \mathrm{~cm}$ in diameter with an area of $1,590 \mathrm{~cm}^{2}$ at the fluid surface. It is connected by nondistensible Tygon tubing to a latex balloon E. Since during distension of the balloon the height of the water in the large reservoir does not measurably change, the externally applied pressure is held constant. The balloon is so constructed that its maximal resting diameter before application of stretch forces is large. The deflated balloon is $0 \mathrm{~cm}$ in diameter and $14 \mathrm{~cm}$ long. The filled balloon is $9.7 \mathrm{~cm}$ in diameter and $14 \mathrm{~cm}$ long, has a volume of $900 \mathrm{cc}$, and supports pressures of $400 \mathrm{~cm}$ of water. Elastic distortion of the balloon is therefore minimal during distension, and the increase in volume during balloon distension is a function of the increase in volume of the viscus segment. Chamber $D$ is an additional water reservoir, and $\mathrm{B}$ and $\mathrm{C}$ are mechanically operated valves, permitting alternate connection of the balloon with chambers $\mathrm{A}$ or $\mathrm{D}$. The diameter of the tubing is $0.5 \mathrm{~cm}$ and its entire length is $290 \mathrm{~cm}$. When chamber $A$ and the tubing are connected, with the fluid surface in chamber A $100 \mathrm{~cm}$ above the balloon, water flows from the tubing at a rate of $49 \mathrm{ml}$ per second.

Pressure measurements are made with a polyethylene catheter leading from the distal Tygon tubing to a no. P23BB Statham transducer. The transducer and balloon are kept at the same level for zero reference. The transducer's output is led into a pressure amplifier, and the pressures are then recorded on the ordinate of a vector oscillograph (Electronics for Medicine, model PR-7 Research Recording Unit). Water flows through a flow-meter F (Wilson 4S-type electrical recording rotameter) before entering the balloon. The output from the flow-meter is led first into a DC amplifier and then into an integrator amplifier calibrated in terms of the volume of water entering the balloon. The volume measurement is recorded on the abscissa of the vector oscillograph. During the oscillographic recording, time is marked at one-second intervals, which appear as dots on the vector tracing.

Experimental procedure. Subjects of the experiment were eight ward patients convalescing from acute illnesses. Most had had occasional disturbances of bowel function in the past, but none had evidence of disease or current disorder of the colon.

Patients were prepared with low saline enemas, the tube and balloon were filled with water, and bubbles were eliminated. The balloon, collapsed against the tubing, was introduced into the sigmoid colon through a proctoscope, and then connected through the water filled system to reservoir $D$, where the fluid surface was at the level of the anterior abdominal wall. The balloon tips were placed 40 to $70 \mathrm{~cm}$ above the anus for sigmoid studies. The subject was placed in the right lateral decubitus position, and operation of the valves was not visible to him. After an interval of 15 minutes, chamber $D$ was disconnected and chamber A suddenly connected to the system. The level of fluid in chamber A was $100 \mathrm{~cm}$ above the balloon. The changes in pressure and volume within the balloon during filling were recorded on the oscilloscope and photographed. The subject was instructed to report promptly any abdominal pain occurring during the procedure. At the end of an experimental run, chamber A was disconnected and chamber D connected to the balloon, resulting in an outflow of water into chamber $\mathrm{D}$ which was then also recorded. Reservoir D remained 


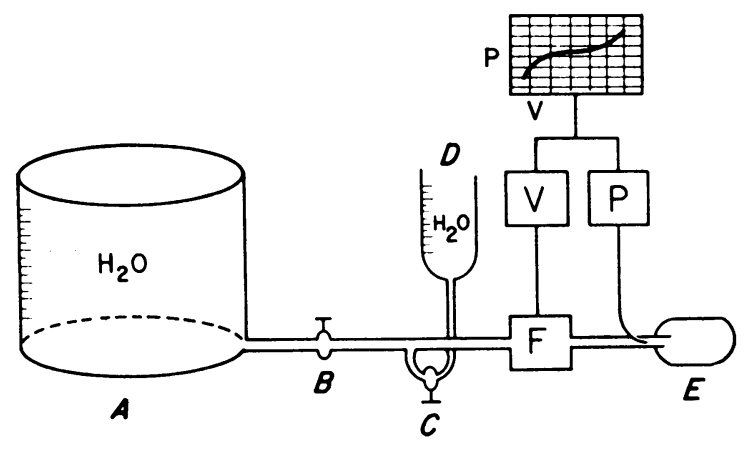

Fig. 1. Diagram of apparatus used. A and D, reservoirs. $B$ and $C$, mechanically operated valves. $F$, flow-meter. E, latex balloon. V, integrator amplifier, and $\mathrm{P}$, pressure transducer and amplifier, connected to vector oscillograph.

open between distensions, with its fluid at the level of the anterior abdominal wall. The distension procedure was repeated after intervals of 3 minutes.

A minimum of six distensions was performed on each subject, after which a pharmacologic agent was administered; then, the same number of distensions was performed as before. Agents used were morphine sulfate, $16 \mathrm{mg}$ subcutaneously, propantheline bromide (ProBanthine), $15 \mathrm{mg}$ intravenously, nitroglycerin, 0.0006 mg sublingually, and the anticholinergic agent $M$ 5023, or pyrophendane (Mead Johnson Co., Evanston, Ill.). After injection of morphine, 15 minutes elapsed before the distensions were resumed, at 3-minute intervals. Distensions were continued immediately after injection of the other agents.

\section{RESULTS}

Distension curves. Figure 2 shows a vector oscillographic recording following a single distension of the sigmoid colon. Examination revealed three phases in the distension record. In phase I, pressure at first increased at a greater rate than volume. In phase II, volume increased at a greater rate than pressure; the major portion of the accommodation of the viscus to the distending force occurred during this phase. A third phase of the distension curves often appeared, during which pressure again increased at a greater rate than volume, as in phase I. Whenever the sensation of visceral pain was reported during these distensions, it was during the third phase. The records were terminated at any report of pain.

Measurement of resistance during distension. The relationship of pressure and volume within the viscus during distension was expressed as $\mathrm{P} /(\mathrm{dV} / \mathrm{dt})=\mathrm{R}$ (Equation 1), where $\mathrm{P}$ equals pressure in millimeters of $\mathrm{Hg}, \mathrm{V}$ equals the volume in milliliters of $\mathrm{H}_{2} \mathrm{O}$, and $\mathrm{dV} / \mathrm{dt}$ equals the rate of flow of water into the balloon in milliliters per second. $\mathrm{R}$ is related to the resistance offered by the viscus wall to the distending force. A decrease in $\mathrm{R}$ would reflect a greater rate of distension. $\mathrm{R}$ is not, however, identical to the resistance measurements expressed in an electrical or flow analog, for it is related to the elastic and viscous properties of the bowel wall. These may change during distension, and thus introduce other variables into the relationship. For each distension record, the $\mathrm{R}$ values were calculated for one-second intervals and plotted against time.

Table I enumerates the pressure, rate of flow, and $R$ values obtained in a single subject (Subject 1) before and after injection of morphine. Seven distensions were performed before and six after injection of morphine. The pressure values tended to be higher and the rate of flow lower than before injection. $\mathrm{R}$ was therefore greater after injection of morphine. In Figure 3, these values are shown plotted against time. The mean values and standard deviations of both series are shown, and graphically illustrate the higher range of $R$ values after morphine.

In Figure 4, results of three studies performed on a single subject at 1 -week intervals are shown. In each study, six distensions taken at 3-minute intervals are plotted. The measurements were

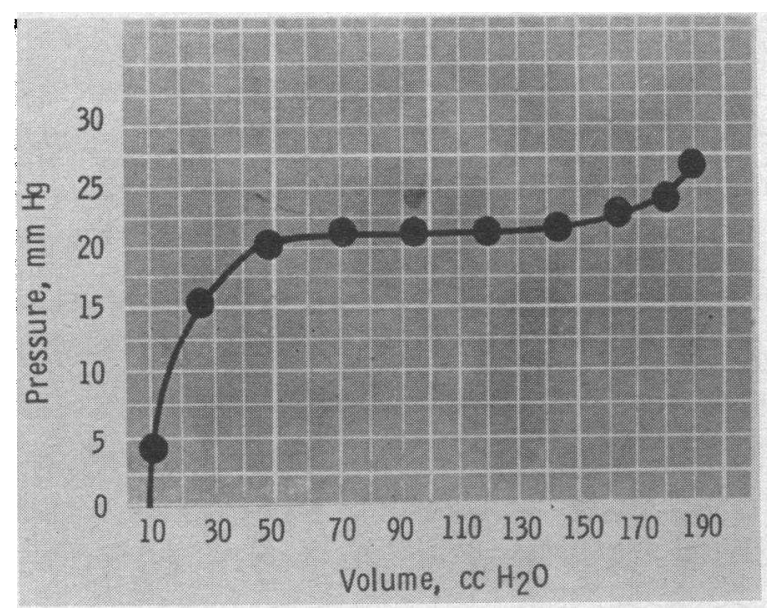

Fig. 2. DiRECT RECORDING OF VECTOR OSCILlOSCOPIC TRACING, INDICATING PRESSURE AND VOLUME RELATIONSHIPS DURING A SINGLE DISTENSION OF THE SIGMOID COLON. Dots are produced by time marker at 1 -second intervals. Pressure shown on ordinate and volume on abscissa. 


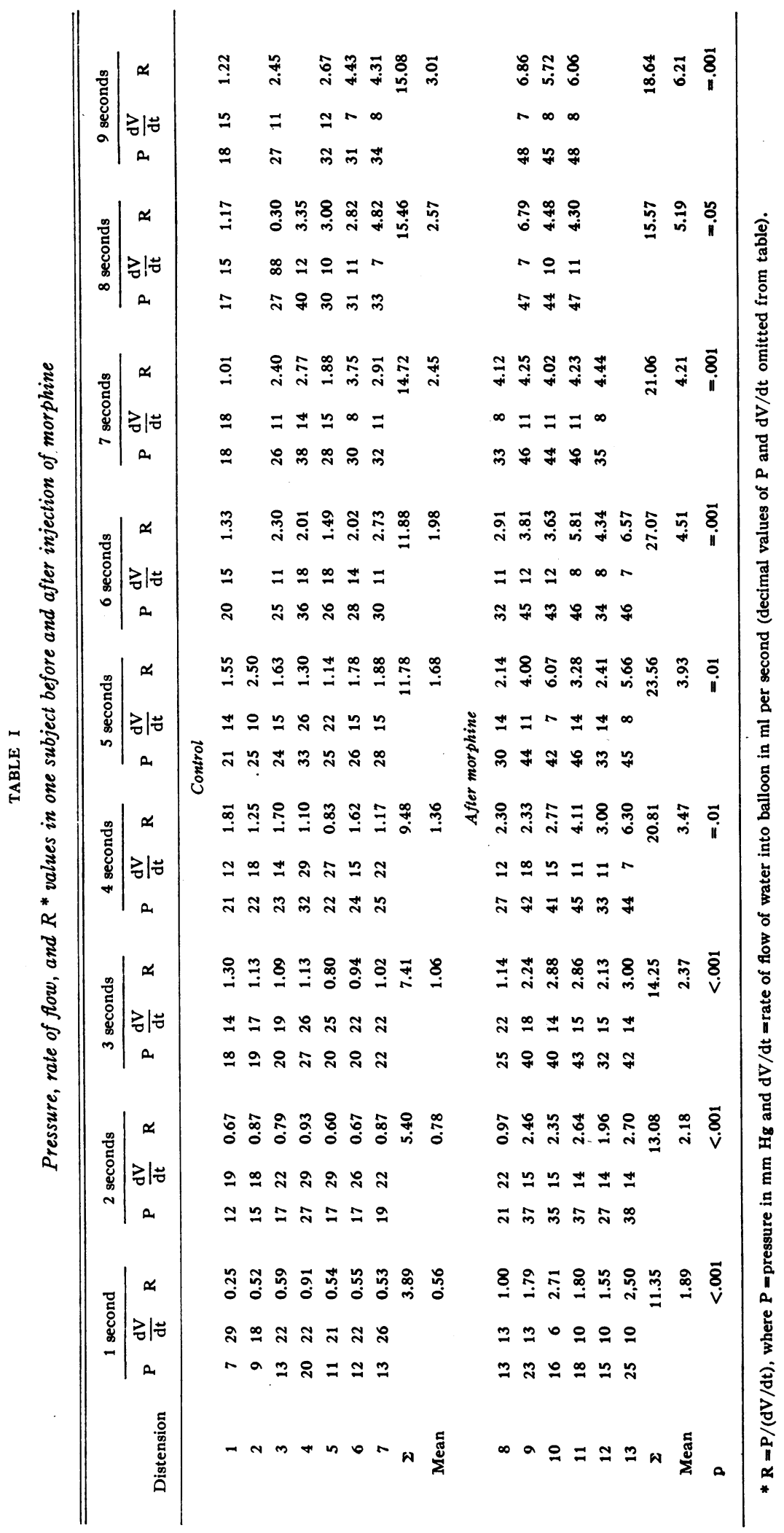




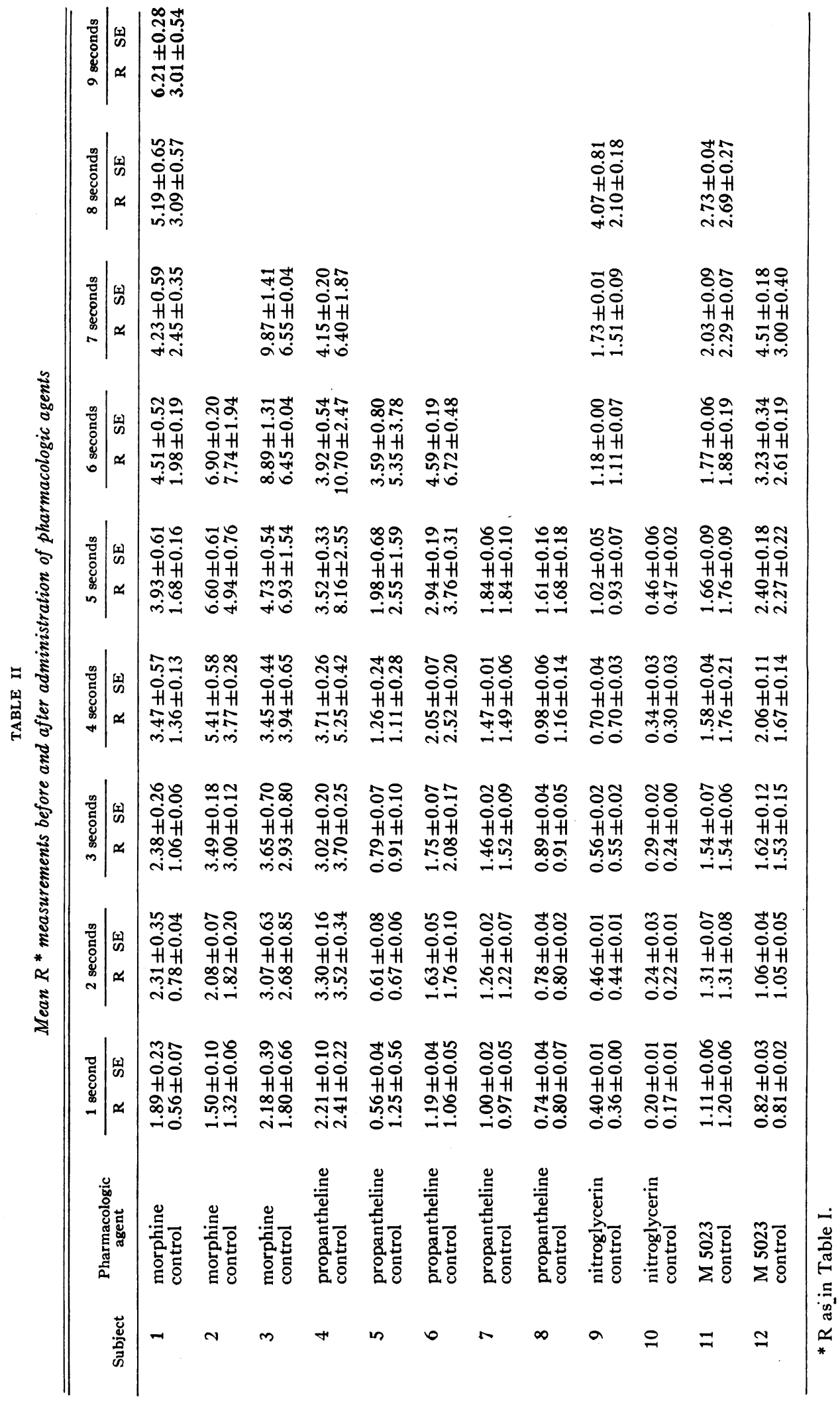




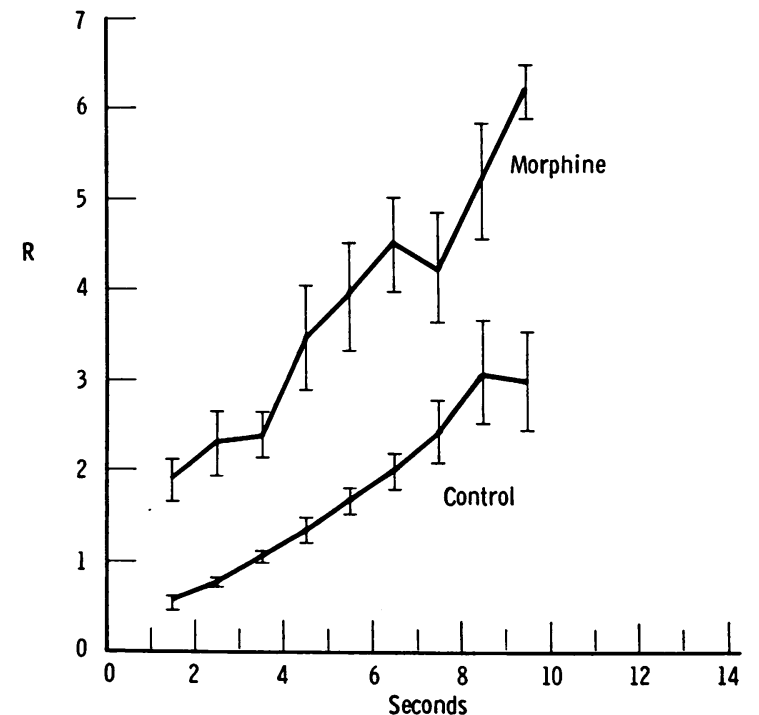

Fig. 3. Changes in $R$ in the sigmoid colon of one SUBJECT, AT INTERVALS FROM ONSET OF DISTENSION, UNDER CONTROL CONDITIONS AND AT HEIGHT OF MORPHINE EFFECT. Each curve presents mean values and SD for 6 distensions.

shown to be very reproducible during the experimental period.

Table II records the $R$ values in 12 subjects before and after injection of a pharmacologic agent.

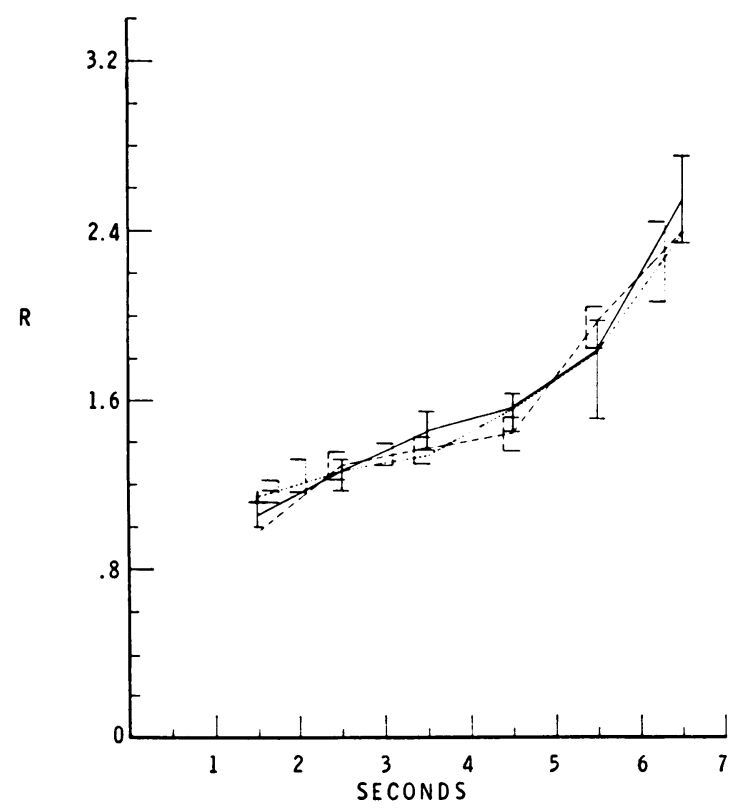

Fig. 4. Results of 3 studies Performed on a Single SUBJECT AT 1-WEek INTERVALS. In each study 6 distensions taken at 3-minute intervals are plotted with SD of measurements.
After morphine, the $\mathrm{R}$ values were uniformly higher in each subject. After propantheline bromide, they were lower in all subjects compared to the controls. After nitroglycerin and after M 5023, no consistent change was noted.

Measurement of accommodation to distension. The accommodation of the viscus wall to each distension by the balloon was expressed in terms of the pressure and volume changes by $\mathrm{P} / \mathrm{V}=\mathrm{k}$ (Equation 2), where $\mathrm{P}$ equals pressure in millimeters of $\mathrm{Hg}, \mathrm{V}$ equals volume in milliliters of $\mathrm{H}_{2} \mathrm{O}$, and $\mathrm{k}$ is a function of the accommodation to distension expressed in these terms. For each distension record, the $\mathrm{k}$ values were calculated at 1-second intervals and plotted against time. In Table III, the accommodation to distension in Subject 1 is shown before and after injection of morphine. As previously seen, the pressure is uniformly higher and the volume uniformly lower after morphine. Figure 5 shows $\mathrm{k}$ for Subject 1 plotted against time. The $\mathrm{k}$ values declined during distension, to a value that described the pressurevolume relationship occurring in the area of maximal distensibility.

When these values were plotted semilogarithmically, graphic analysis of the records of all subjects revealed a final component that occurred in the area of maximal distensibility and a pre-

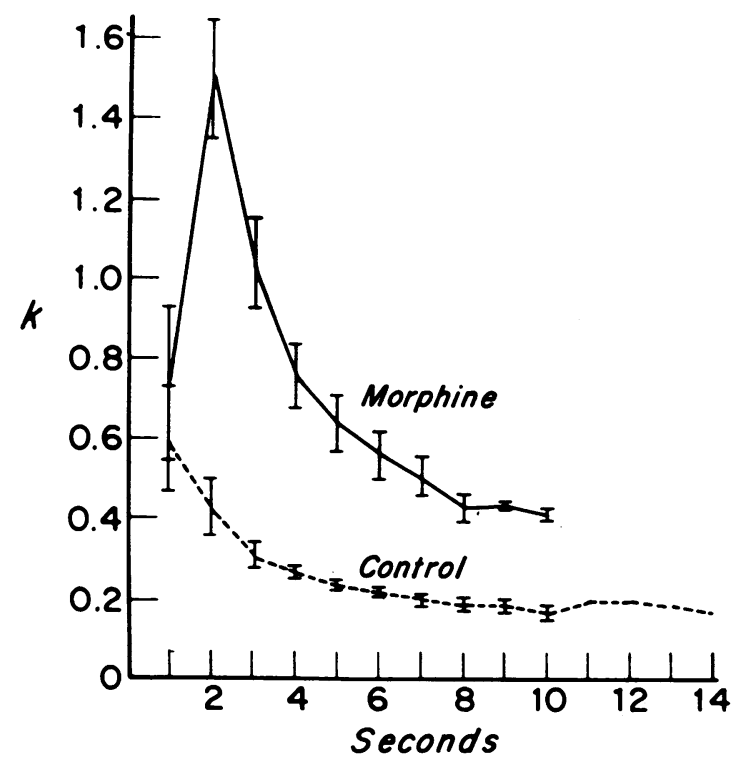

Fig. 5. The ACCOMMODATION TO DISTENSION k (EQUATION 2) AT INTERVALS AFTER THE ONSET OF DISTENSION IN SUBJECT 1 UNDER CONTROL CONDITIONS AND AT THE HEIGHT OF MORPHINE EFFECT. 
ceding linear component (see Figure 6) that occupied most of the distension record. The latter was termed the "accommodation component" $k$ '. It represented a linear relationship of pressure and volume, occurring when the viscus accommodated to the distension stimulus. The slope and half-life of the accommodation component were a function of the rate of accommodation of the viscus to the distension stimulus. When the intercept of the accommodation component was extended back to zero time, it identified a pressure-volume relationship that existed in the viscus in the resting state before distension. This pressure-volume relationship provided a physiological measurement of the state of contractility or tonus in the viscus wall before distension. The slope and intercept of the accommodation component were calculated by $\log \mathrm{k}^{\prime}=\mathrm{mt}+\log \mathrm{k}_{0}^{\prime}$ (Equation 3), where $\mathrm{m}$ is the slope and $\mathrm{k}_{0}^{\prime}$ the intercept. Values were fitted by the method of least squares to give the most accurate slope and intercept. The half-life of the accommodation component $t_{\frac{1}{2}}$ was calculated by $t_{\frac{1}{2}}=\ln 2 / \mathrm{m}$ (Equation 4).

Figure 6 shows the accommodation component

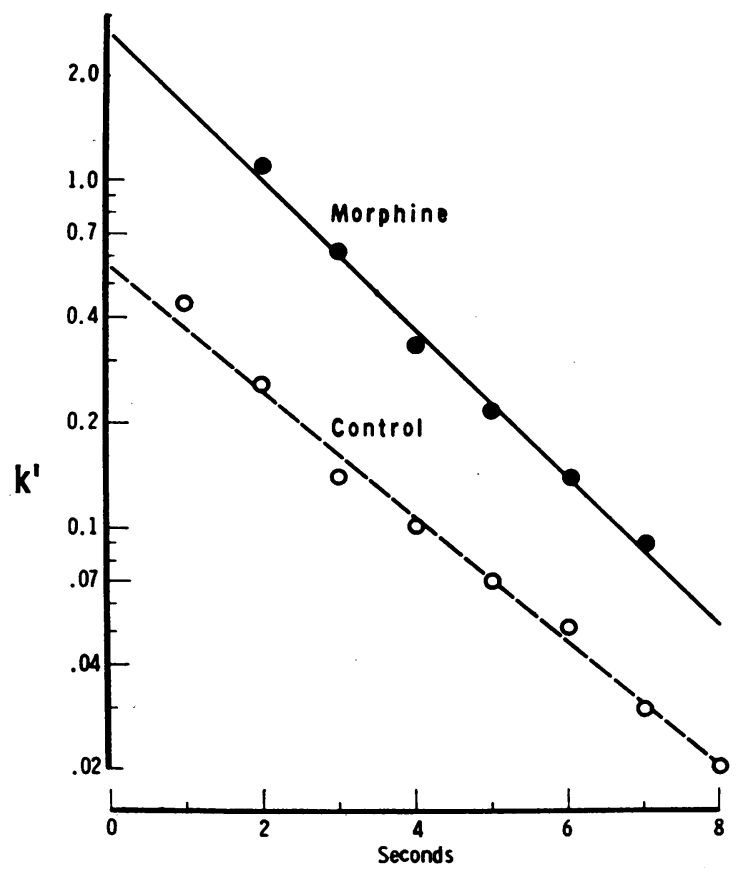

Fig. 6. The accommodation COMPONENT $k^{\prime}$ Before AND AFTER THE ADMINISTRATION OF MORPHINE IN SUBJECT 1.
TABLE IV

\begin{tabular}{|c|c|c|c|c|}
\hline Subject & $\begin{array}{c}\text { Pharmacologic } \\
\text { agent }\end{array}$ & $\mathbf{k}^{\prime} 0^{*}$ & $-t \frac{1}{2}$ & $-m$ \\
\hline 1 & $\begin{array}{l}\text { morphine } \\
\text { control }\end{array}$ & $\begin{array}{l}2.72 \\
0.57\end{array}$ & $\begin{array}{l}1.39 \\
1.69\end{array}$ & $\begin{array}{l}0.49 \\
0.41\end{array}$ \\
\hline 2 & $\begin{array}{l}\text { morphine } \\
\text { control }\end{array}$ & $\begin{array}{l}4.78 \\
2.49\end{array}$ & $\begin{array}{l}1.01 \\
1.02\end{array}$ & $\begin{array}{l}0.69 \\
0.68\end{array}$ \\
\hline 3 & $\begin{array}{l}\text { morphine } \\
\text { control }\end{array}$ & $\begin{array}{l}5.96 \\
4.33\end{array}$ & $\begin{array}{l}1.58 \\
0.89\end{array}$ & $\begin{array}{l}0.44 \\
0.77\end{array}$ \\
\hline 4 & $\begin{array}{l}\text { propantheline } \\
\text { control }\end{array}$ & $\begin{array}{l}6.48 \\
5.85\end{array}$ & $\begin{array}{l}1.14 \\
0.99\end{array}$ & $\begin{array}{l}0.61 \\
0.69\end{array}$ \\
\hline 5 & $\begin{array}{l}\text { propantheline } \\
\text { control }\end{array}$ & $\begin{array}{l}0.23 \\
0.49\end{array}$ & $\begin{array}{l}0.64 \\
0.75\end{array}$ & $\begin{array}{l}1.09 \\
0.93\end{array}$ \\
\hline 6 & $\begin{array}{l}\text { propantheline } \\
\text { control }\end{array}$ & $\begin{array}{l}3.62 \\
3.47\end{array}$ & $\begin{array}{l}1.02 \\
0.94\end{array}$ & $\begin{array}{l}0.67 \\
0.73\end{array}$ \\
\hline 7 & $\begin{array}{l}\text { propantheline } \\
\text { control }\end{array}$ & $\begin{array}{l}2.79 \\
4.46\end{array}$ & $\begin{array}{l}0.99 \\
0.88\end{array}$ & $\begin{array}{l}0.69 \\
0.78\end{array}$ \\
\hline 8 & $\begin{array}{l}\text { propantheline } \\
\text { control }\end{array}$ & $\begin{array}{l}2.41 \\
2.66\end{array}$ & $\begin{array}{l}0.79 \\
0.83\end{array}$ & $\begin{array}{l}0.88 \\
0.84\end{array}$ \\
\hline 9 & $\begin{array}{l}\text { nitroglycerin } \\
\text { control }\end{array}$ & $\begin{array}{l}0.74 \\
0.41\end{array}$ & $\begin{array}{l}1.01 \\
1.19\end{array}$ & $\begin{array}{l}0.69 \\
0.58\end{array}$ \\
\hline 10 & $\begin{array}{l}\text { nitroglycerin } \\
\text { control }\end{array}$ & $\begin{array}{l}0.78 \\
1.28\end{array}$ & $\begin{array}{l}0.81 \\
0.52\end{array}$ & $\begin{array}{l}0.82 \\
1.35\end{array}$ \\
\hline 11 & $\begin{array}{l}\text { M } 5023 \\
\text { control }\end{array}$ & $\begin{array}{l}2.08 \\
1.86\end{array}$ & $\begin{array}{l}1.14 \\
1.25\end{array}$ & $\begin{array}{l}0.55 \\
0.51\end{array}$ \\
\hline 12 & $\begin{array}{l}\text { M } 5023 \\
\text { control }\end{array}$ & $\begin{array}{l}1.13 \\
0.85\end{array}$ & $\begin{array}{l}1.54 \\
1.90\end{array}$ & $\begin{array}{l}0.44 \\
0.35\end{array}$ \\
\hline
\end{tabular}

${ }^{*} \mathrm{k}^{\prime}{ }_{0}=$ intercept of accommodation component $\mathrm{k}^{\prime} ; \mathrm{t}$ $=$ half-life of $\mathrm{k}^{\prime} ; \mathrm{m}=$ slope.

before and after injection of morphine in Subject 1. The slopes were similar for both measurements, and demonstrated that the rate of distension or accommodation of the viscus to the distension stimulus was not appreciably changed after morphine. In contrast, the value of the intercept of the accommodation component extended back to zero time quadrupled after morphine. This finding indicated that the morphine-induced change recorded here was present before application of the distension stimulus, and revealed an increase in the pressure-volume or tonus level of the viscus while it was in the resting state.

Table IV records measurements of the accommodation component before and after administration of the pharmacologic agents. The intercept was always elevated after morphine. Slope and $t \frac{1}{2}$ did not change uniformly after the agents were given. 


\section{DISCUSSION}

In this study, an attempt was made to develop parameters of measurement that would enable in vivo investigation of certain properties of the human colon. These properties were related to the distensibility of the colon, and to functions that reflected tonus or spasticity of the viscus wall. From measurements of pressure and volume, expressions were developed to evaluate the ease of distension during application of the stimulus.

The measurements are complicated by a number of factors that are not included in these in vivo determinations. First, elastic and viscous properties of the colonic wall may change during distension. Second, the most accurate measurement of the distending pressure on the bowel wall would be made with a determination of transmural pressure, the difference between intraluminal and intraperitoneal pressure. The intraperitoneal pressure would be expected to be small compared to the intraluminal pressure applied; the intraperitoneal pressure, however, could rise during application of the distension stimulus, thus decreasing the pressure gradient. If, in these measurements, the accommodation to distension were maximal, volume would increase maximally and pressure minimally. If accommodation to distension were minimal, then pressure would change maximally and volume minimally. The pressurevolume relationship recorded enabled instantaneous measurement of these factors.

In this study, morphine increased the pressurevolume relationship during distension. This effect appeared to be related to an increase in the initial state of contractility or tonus of the muscular fibers of the viscus wall, without any change occurring in the rate at which the viscus was able to distend and accommodate to the applied stimulus. In other studies, administration of morphine produced a decrease in propulsive activity and a tonic spasticity of the intestinal musculature (1). Both of these effects are related to the constipating activity of morphine. Further studies of the pressure-volume relationships in the presence of constipation due to the action of other drugs and to the irritable-colon syndrome would be of interest to determine similarities to or differences from the findings obtained with morphine.

The decrease in the pressure-volume relation- ship after propantheline agrees with previous finding related to this group of agents, which cause a decrease in tone and in amplitude and frequency of peristaltic contractions in the colon (2). With the present method, it should be possible to study the in vivo effects and to quantify the effects of other pharmacologic agents on these functions in human subjects.

The term "accommodation" has been given to the ability of tissues to react to potentially harmful stimuli so as to preserve their normal viability (3). The accommodating response of the colon to the distending force has been thought to be greater with stimuli of low intensity and to be associated with the prevention of pain and tissue damage (4). In the present study, the onset of visceral pain was not associated with any absolute levels of pressure or volume. It was, however, associated with a sudden increase in pressure without corresponding increase in volume, near the limit of maximal distensibility of the viscus. The findings here would, therefore, appear to agree with the possibility that pain occurs when the stretching force applied to the muscular fibers is great, and pain could be associated with a warning of potential or beginning tissue-damage. With more data, the point of onset of visceral pain could be defined more accurately in terms of these derived functions.

The vector curves of pressure and volume obtained in this study are similar to pressure-volume curves seen after distension of the urinary bladder in animals (5), in which similar pressure levels, from 10 to $40 \mathrm{~mm} \mathrm{Hg}$, were employed and phases I to III were also seen. In the urinary bladder studies, changes in the pressure-volume curves and bladder tone were shown after section of the hypogastric nerves (6). The vector curves and the functions derived in the present study from the pressure, flow, and volume measurements should also be expected to be useful in recording alterations in physical properties of the intestinal wall occurring in a variety of disease states, as well as in evaluating the effects of therapeutic agents on the intestine.

\section{SUM MARY}

The motility of the human colon, customarily measured in terms of spontaneous phasic varia- 
tions in intraluminal pressure, has been further defined in terms of an intraluminal pressure-volume relationship. During distension with water of a balloon lying in a segment of sigmoid colon, pressure, volume, and rate of flow of water into the balloon were measured simultaneously with strain gauge and flow-meter, respectively. The outputs of these instruments were fed into a vector oscilloscope, permitting mathematical analysis of these relationships at various stages of distension. Elastic distortion of the balloon was minimal, since its diameter was larger than the maximal diameter of the viscus.

In the colons of normal subjects, morphine increased and propantheline decreased the resistarce of the viscus to distension. These drugs did not, however, alter the rate of accommodation to distension. Visceral pain was noted only when the limit of distensibility of the viscus was approached.

This new parameter of intestinal motility, reflecting sustained as opposed to phasic contractions, is expected to be useful in recording the alteration in physical properties of the intestinal wall in a variety of disease states, as well as in evaluating the effects of therapeutic agents on the intestine.

\section{ACKNOWLEDGMENTS}

We thank Dr. Marvin Sleisenger for assistance in initiating the project, Dr. Daniel Lukas for advice on the selection of a flow-meter, Dr. Melvin Schwartz and Mrs. Helen Fuss for aiding the biostatistical analyses, and the Mead Johnson Co., Evanston, Ill., for partial support of the project.

\section{REFERENCES}

1. Krueger, H. M. The action of morphine on the digestive tract. Physiol. Rev. 1937, 17, 618.

2. Goodman, L. S., and Gilman, A. The Pharmacological Basis of Therapeutics. New York, MacMillan, 1958, p. 564.

3. Fulton, J. F. A Textbook of Physiology, 17th ed. Philadelphia, Saunders, 1955, p. 19.

4. Lipkin, M., and Sleisenger, M. H. Studies of visceral pain: measurements of stimulus intensity and duration associated with the onset of pain in esophagus, ileum and colon. J. clin. Invest. 1958, 37, 28.

5. Simeone, F. A., and Lampson, R. S. Cystometric study of function of the urinary bladder. Ann. Surg. 1937, 106, 413.

6. Langworthy, O. R., Reeves, D. L., and Tauber, E. S. Autonomic control of the urinary bladder. Brain 1934, 57, 266. 